\title{
REVIEW
}

\section{Changes and convergences in the teaching of journalism and journalistic practices}

Claudia Quadros, Kati Caetano e Álvaro laranjeira. Jornalismo e convergência. Ensino e práticas Profissionais, Covilhã: Livros LabCom, 2011

\section{Reviewed by Bárbara Garrido de Paiva Schlaucher}

The current scenario of media and language convergence represents nowadays a cultural transformation. The advent of new digital technologies, coupled with the intense flow of information through multiple platforms, encourages individuals to establish connections among dispersed media products. With faster and easier access to an abundant amount of content, the behavior of the audience' and media companies undergoes profound changes. The digital revolution and the resulting transformation of the relationship between people and media not only affect the way that news content is produced and experienced by society, but also the teaching of the profession and the daily lives of individuals, journalists or not.

This is the keynote of the book Jornalismo e convergencia: ensino e práticas profissionais (Journalism and convergence: education and professional practices), organized by Professors Claudia Quadros, Kati Caetano and Alvaro Laranjeira, from the Postgraduate Program in Communication and Languages at Tuiuti University in the state of Paraná, Brazil, and members of the PROCAD/CAPES research team $O$ Ensino de Jornalismo na Era da Convergencia (The Teaching of Journalism in the Convergence Era). The collection of papers is divided into two parts. The first one, "Pensar o ensino de Jornalismo Digital" (Thinking about the teaching of Digital Journalism), brings theoretical and methodological reflections on the field of communication and its relationship to digital technologies, in particular the learning process of journalism and news production in cyberspace. The four chapters are the result of studies conducted by professors from Brazil, Portugal, Mexico and Spain. The second part consists of five chapters that present 
partial results from different research works and reports on teaching experiences in journalism courses concentrated in the southern region of Brazil. The empirical approach, based on the review of concepts and theories, provides the discussion and evaluation of teaching methods and the practice of journalism in the context of convergence as well as of recent changes in curricula in order to keep up with the rapid technological development.

Following the order of reflection proposed by the organizers of the collection, we seek to highlight the most relevant aspects concerning the subject presented here, in a special dialog with the authors of the book. To do so, it is important to emphasize that we share the view that the advent of digital media will not replace the traditional means of communication. Accordingly, "the emerging convergence paradigm assumes that old and new media will interact in increasingly complex ways" (JENKINS, 2009, p. 33).

In this sense, the texts presented in the collection were organized by Quadros, Caetano and Laranjeiras (2011) in order not to restrict the work to the sphere of production and distribution of journalistic information. The authors, in general, show technological convergence as a process that also occurs when people take control of the media. In this way, they propose to think about the changes regarding the practice of journalism, the training of a new generation of professionals, the role of journalists in the information society and the attitude of the audience in this new scenario.

The digitization of the news production process, which started at the end of the 1980s, changed the work routine of thousands of journalists around the world. Not only has the work environment undergone transformations, but also the tasks performed by information professionals. Moreover, the speed and the large offer of contents with easy access provided by the advent of the worldwide computer network have been changing the conception of time and space in journalism and pose new questions concerning professional ethics and objectivity.

These findings make clear the fact that the mastery of techniques is not enough to act in the market.. The "fear" that still haunts news organizations with regard to a possible structural collapse in the communication field, as shown by Elizabeth Saad Correa (2011, p. 61), is rooted in "the purposes of information production and the role of journalism in the contemporary society". Thus, we show the importance of training as a basis for reflection on the social role of journalism in the current context of unlimited access and exchange 
of information. Technologies evolve at a fast pace and are constantly changing. In this way, focusing the training process of journalism students on operational aspects does not satisfy the requirements of the market. It is necessary to incorporate disciplines that help students reflect on the profession in the media convergence era.

As recommended by the Portuguese researcher João Canavilhas in the first chapter of the book, journalism schools must study the potential of the new technologies and reflect on the Communication Theories in light of the new digital reality in order to propose informative languages and formats and identify "economic models that exploit a market still little aware of the potential of the Internet as a privileged channel of distribution of information" (CANAVILHAS, 201 1, p. 24). The author's observation recurs throughout the book, which draws attention to the need for teaching Web journalism to the same extent as the traditional models.

Nowadays, print newspapers, radios and TV newscasts have their own online versions. Each day, media companies seek to give these products a distinct identity so as to satisfy the demands for access to information and participation of individuals that no longer subject themselves to the "mass consumption routine". Additionally, there is a complementary relation between different languages in the online environment, culminating in multimedia, hypermedia and interactive products. Consequently, the need for a multiplatform professional arises - someone who is capable of acting skillfully in different media in order to construct narratives, not simply information (MOSCHETTA; RASERA, 2011) (CALVO; CORPUS; LOZANO, 2011). As if this were not enough, - even if one does not work directly with cyberjournalism - news production in the context of convergence requires multitask journalists due to the disappearance of positions as a consequence of the digitization of the newsrooms.

Thus, journalism courses must update their curricula so as to take the maximum possible advantage of the students, who "already belong to a generation of native Internet users" and "conceive the structuring of journalistic information in a format appropriate for the digital media", as explained by Luciana Mielniczukz and collaborators under her guidance in the article that opens the second part of the book. However, it is necessary to go beyond this. In a scenario of free circulation of messages, in which the means of production, distribution and access to information are no longer concentrated in the traditional media, but begin to follow the network or rhizomatic model, the boundaries between sender and receiver start to vanish. Therefore, the amount of voices, discourses and information available online grows exponentially. The future professionals must learn 
to check and deal with the utilizations of content by the audience, now also a producer (CAETANO; BARBOSA; QUADROS, 2011).

In this way, the authors maintain that journalism schools must prepare their students to: recognize the different forms of consumption by users, in order to design and present information in a manner that best suits the media and the demands for interaction and participation in contemporary society; to relate to an audience that is active and plays a leading role in the processes of production and sharing of contents; to master strategies for searching out and selecting information in the network, keeping in mind ethics and journalists ' social responsibility with regard to the accurate investigation of the facts; and to reflect critically on the production and the concept of journalism in the media convergence era. The need for professionals trained for this new scenario opens the door to more effective communication between the academy and the market. Only through this dialogue, already initiated in the book discussed here, it will be possible to exploit the full potential of convergence, innovating and offering solutions not just technological but mainly social, professional and methodological for the teaching and practice of journalism.

\section{REFERENCES}

CAETANO, Kati; BARBOSA, Marialva; QUADROS, Claudia. Dispositivos e práticas jornalísticas em um mundo sem fronteiras. In: QUADROS, Claudia; CAETANO, Kati; LARANJEIRA, Álvaro (Orgs.). Jornalismo e Convergência: ensino e prática professionais. Covilhã: Livros LabCom, 2011. p. 75-99.

CALVO, Santiago Tejedor; CORPUS, Roberto Silva; LOZANO, Fernando Esquivel. La formación Del ciberperiodista 2.0: retos, competencias y habilidades Del comunicador 2.0. In: QUADROS, Claudia; CAETANO, Kati; LARANJEIRA, Álvaro (Orgs.). Jornalismo e Convergência: ensino e prática professionais. Covilhã: Livros LabCom, 2011. p. 27-46.

CORRÊA, Elizabeth Saad. Estratégias de conteúdo para meios digitais: ciclos de reconfiguração e os rumos para um novo período. In: QUADROS, Claudia; CAETANO, Kati; LARANJEIRA, Álvaro (Orgs.). Jornalismo e Convergência: ensino e prática professionais. Covilhã: Livros LabCom, 2011. p. 47-74.

JENKINS, Henry. Cultura da convergência. São Paulo: Aleph, 2009.

MIELNICZUK, Luciana; MISSAU, Lucas Durr; LAMMEL, Iuri; BIANCHINI, Maíra; WANGLON, Paolla. Infocampus como espaço para o ensino e a aprendizagem de jornalismo digital. In: QUADROS, Claudia; CAETANO, Kati; LARANJEIRA, Álvaro (Orgs.). Jornalismo e Convergência: ensino e prática professionais. Covilhã: Livros LabCom, 2011. p.103-124. 
MOSCHETTA, Andressa Pacheco; RASERA, Marcella. Jornalismo na implosão da convergência midiática. In: QUADROS, Claudia; CAETANO, Kati; LARANJEIRA, Álvaro (Orgs.). Jornalismo e Convergência: ensino e prática professionais. Covilhã: Livros LabCom, 2011. p. 189-212.

QUADROS, Claudia; CAETANO, Kati; LARANJEIRA, Álvaro (Orgs.). Jornalismo e Convergência: ensino e prática professionais. Covilhã: Livros LabCom, 2011.

Bárbara Garrido de Paiva Schlaucher is journalist and Master student supported by a federal scholarship (CAPES) in the Postgraduate Program in Communication at the Federal University of Juiz de Fora, state of Minas Gerais, Brazil. E-mail: babischlaucher@gmail.com. 